\title{
PDCD4 Gene
}

National Cancer Institute

\section{Source}

National Cancer Institute. PDCD4 Gene. NCI Thesaurus. Code C94698.

This gene may be involved in apoptosis and translation. 